\title{
ANTIBODY RESPONSE TO RUBELLA RIBONUCLEOPROTEIN COMPONENT AFTER NATURAL INFECTION AND AFTER IMMUNIZATION
}

\author{
Linda Ho-Terry and A. CoHEN \\ Department of Medical Microbiology, School of Medicine, University College London, \\ University Street, London WC1E 6JJ
}

Summary. Antibody to the ribonucleoprotein component of rubella virus occurs in only a proportion of patients with clinical rubella and is rarely present in individuals after administration of RA27/3 live attenuated virus vaccine.

\section{INTRODUCTION}

The development of antibody to the rubella virus internal ribonucleoprotein component in some patients after recent rubella has been demonstrated (Ho-Terry and Cohen, 1979). More studies on the development of this antibody after natural infection and vaccination with the live attenuated RA27/3 vaccine are reported here.

\section{MATERIALS AND METHODS}

Cells, virus, culture media and buffers were as previously described (Ho-Terry and Cohen, 1979).

Radioactive isotope. L- $\left(5-{ }^{3} \mathrm{H}\right)$ arginine monohydrochloride $(8.8 \mathrm{Ci} / \mathrm{mmol})$ was obtained from the Radiochemical Centre, Amersham, Bucks.

Sera from patients with clinical rubella were supplied by Dr T. H. Flewett, Regional Virus Laboratory, East Birmingham Hospital, Birmingham. Pre- and post-vaccination sera were supplied by Professor J. A. Dudgeon, Institute of Child Health, London, and Dr A. J. Beale, The Wellcome Research Laboratories, Beckenham, Kent.

Goat anti-human IgM and IgG sera were obtained from Miles Laboratories Ltd Slough, Berks.

Preparation of radioactively labelled rubella virus was as previously described (Ho-Terry and Cohen, 1979).

Separation of internal ribonucleoprotein component was as previously described (Ho-Terry and Cohen, 1979).

Haemagglutination inhibition test was as described by Liebhaber (1970).

Radioimmune precipitation tests. For titration of antibody against rubella virus, $0 \cdot 1 \mathrm{ml}$ of test serum, diluted 1 in 10 , was mixed with $0.1 \mathrm{ml}$ of ${ }^{3} \mathrm{H}$-arginine-labelled purified rubella virus and held overnight at $4^{\circ} \mathrm{C}$. An equal volume of goat anti-human IgM serum suitably diluted to give optimal precipitation (Horwitz and Scharff, 1969) was added and the mixture held for another 24 $\mathrm{h}$ at $4^{\circ} \mathrm{C}$. Radioactively labelled rubella virus-rubella specific human IgM-goat anti-human IgM complexes, collected by centrifugation, were washed and counted as previously described 
(Ho-Terry and Cohen, 1979). Five replicate tests of a similarly diluted control serum, having a rubella haemagglutination inhibition titre of $<4$ were included in each assay and the mean and standard deviation of radioactivity precipitated were calculated. Test sera were considered positive for rubella specific IgM when the difference between ${ }^{3} \mathrm{H}$-radioactivity precipitated by test serum and the mean ${ }^{3} \mathrm{H}$-radioactivity precipitated by control serum equalled or exceeded three standard deviations.

For titration of antibody against rubella ribonucleoprotein component, the method was essentially the same except that serum samples were tested undiluted against ribonucleoprotein component, and goat anti-human IgG serum was used.

\section{RESULTS}

Antibodies after clinical rubella. The results of tests of serum samples taken from patients with clinical rubella are summarised in table I. Diagnostic (fourfold) rises of haemagglutination-inhibition titre were demonstrable in two of five patients but the diagnosis of current rubella in all five patients was confirmed by finding rubella-specific IgM. These results are similar to those of Pattison and Dane (1975).

Three patients developed antibody to the rubella ribonucleoprotein component. Although of the IgG class, their incidence was unrelated to the level of haemagglutination inhibition antibody.

Antibodies after rubella vaccination. The results of tests on serum samples taken before and 1-2 months after rubella vaccination are summarised in table II. Compared with haemagglutination-inhibition titres after natural infection, those after vaccination are strikingly low. Of the 16 paired serum samples examined for antibody to the rubella ribonucleoprotein component, only one post-vaccination serum was found to be positive and this was the serum with the highest titre of haemagglutination-inhibition antibody.

TABLE I

Antibody response to rubella haemagglutinin and internal ribonucleoprotein component after clinical rubella infection.

\begin{tabular}{cc|ccc}
\hline $\begin{array}{c}\text { Patient } \\
\text { no. }\end{array}$ & $\begin{array}{c}\text { Days after } \\
\text { onset of rash }\end{array}$ & $\begin{array}{c}\text { Haemagglutination- } \\
\text { inhibition titre }\end{array}$ & $\overbrace{\begin{array}{l}\text { IgM against } \\
\text { whole virus }\end{array}}^{\text {Radioimmune precipitation: }} \begin{array}{c}\text { IgG against } \\
\text { ribonucleoprotein }\end{array}$ \\
\hline 1 & 5 & 128 & + & + \\
2 & 15 & 256 & + & + \\
3 & 10 & 128 & + & - \\
4 & 13 & 256 & + & + \\
5 & 13 & 512 & + & + \\
& 15 & 128 & + & + \\
\hline
\end{tabular}

$+=$ Precipitation; $-=$ no precipitation. 
TABLE II

Antibody response to rubella haemagglutinin and internal ribonucleoprotein component after vaccination with $R A 27 / 3$.

\begin{tabular}{|c|c|c|c|}
\hline $\begin{array}{l}\text { Vaccinee } \\
\text { no. }\end{array}$ & $\begin{array}{l}\text { Time of } \\
\text { serum sampling }\end{array}$ & $\begin{array}{c}\text { Haemagglutination- } \\
\text { inhibition titre }\end{array}$ & $\begin{array}{l}\text { Radioimmune precipitation: } \\
\text { IgG against ribonucleoprotein }\end{array}$ \\
\hline \multirow[t]{2}{*}{1} & Prevaccination & $<4$ & - \\
\hline & Postvaccination & 8 & - \\
\hline \multirow[t]{2}{*}{2} & Prevaccination & $<4$ & - \\
\hline & Postvaccination & 256 & + \\
\hline \multirow[t]{2}{*}{3} & Prevaccination & 32 & - \\
\hline & Postvaccination & 64 & - \\
\hline \multirow[t]{2}{*}{4} & Prevaccination & $<4$ & - \\
\hline & Postvaccination & 8 & - \\
\hline \multirow[t]{2}{*}{5} & Prevaccination & $<4$ & - \\
\hline & Postvaccination & 16 & - \\
\hline \multirow[t]{2}{*}{6} & Prevaccination & $<4$ & - \\
\hline & Postvaccination & 32 & - \\
\hline \multirow[t]{2}{*}{7} & Prevaccination & $<4$ & - \\
\hline & Postvaccination & 32 & - \\
\hline 8 & $\begin{array}{l}\text { Prevaccination } \\
\text { Postvaccination }\end{array}$ & $\begin{array}{l}<4 \\
64\end{array}$ & $\bar{z}$ \\
\hline \multirow[t]{2}{*}{9} & Prevaccination & $<4$ & - \\
\hline & Postvaccination & 64 & - \\
\hline \multirow[t]{2}{*}{10} & Prevaccination & $<4$ & - \\
\hline & Postvaccination & 128 & - \\
\hline \multirow[t]{2}{*}{11} & $\begin{array}{l}\text { Prevaccination } \\
\text {. }\end{array}$ & $<4$ & - \\
\hline & Postvaccination & $<4$ & - \\
\hline \multirow[t]{2}{*}{12} & Prevaccination & $<4$ & - \\
\hline & Postvaccination & 32 & - \\
\hline \multirow[t]{2}{*}{13} & Prevaccination & $<4$ & - \\
\hline & Postvaccination & 64 & - \\
\hline \multirow[t]{2}{*}{14} & Prevaccination & $<4$ & - \\
\hline & Postvaccination & 128 & - \\
\hline \multirow[t]{2}{*}{15} & Prevaccination & $<4$ & - \\
\hline & Postvaccination & 128 & - \\
\hline \multirow[t]{2}{*}{16} & Prevaccination & $<4$ & - \\
\hline & Postvaccination & 4 & - \\
\hline
\end{tabular}

\section{Discussion}

By a highly sensitive technique of radioimmune precipitation, antibody to the rubella ribonucleoprotein component was demonstrated in sera from patients with recent but not remote rubella infection (Ho-Terry and Cohen, 1979). Our results presented here confirm this observation though the antibody was found in sera from only three of five patients with clinical rubella (table I). In contrast, only one of 16 individuals vaccinated with rubella vaccine RA27/3 developed this antibody (table II). This lack of response may be related to the poor response to vaccination as measured by the haemagglutination-inhibition test, or possibly to a difference in the response to viral antigens after natural infection and vaccination.

Le Bouvier (1969a) described two distinct precipitating antigens of rubella, theta and iota. Experimentally, antibodies to iota antigen are produced after injection of the rubella ribonucleoprotein component into rabbits (Cappel and De Cuyper, 1976), which suggests a close relationship if not identity between 
these components. Significantly, with the exception of Le Bouvier (1969b), who regularly found antibodies to the iota antigen after natural infection, other workers have found these antibodies, like those to the rubella ribonucleoprotein component reported here, in only a small proportion of patients after rubella (Horstmann et al., 1970; Paul et al., 1974; Ho-Terry and Cohen 1979). After vaccination, Cendehill and HPV-77 vaccines evoked minimal levels of antibody to the iota antigen in a small proportion of vaccinated individuals, mainly children (McCollum et al., 1969; Horstmann et al., 1970; Paul et al., 1974). In contrast, Le Bouvier and Plotkin (1971) detected antibodies to iota antigen in all but one of 35 individuals vaccinated with an RA27/3 vaccine. Of the currently available vaccines, RA27/3 is reported to be the most effective (Le Bouvier and Plotkin, 1971; Best et al., 1979; Freestone, 1979) and to produce an antibody response more closely resembling that of natural infection (Le Bouvier and Plotkin, 1971), which may account for its enhanced capacity to produce antibodies against the iota antigen. However, our results (table II) show that the antibody response to RA27/3 does not always equal or approach that of natural infection even in the absence of pre-existing rubella antibody which may interfere with the response (Freestone, 1978). Indeed, only one individual of our series who received RA27/3 responded with a haemagglutination inhibition titre as high as 256 and this was the only one to develop antibody to the rubella ribonucleoprotein component. The failure of the other members of this series to produce this antibody may thus be related to the poverty of the overall antibody response to vaccination with RA27/3. If so, screening of serum samples for antibody to rubella ribonucleoprotein component as well as haemagglutination-inhibition antibody may provide an additional means of assessing the efficacy of rubella vaccines.

We thank Dr T. H. Flewett, Professor J. A. Dudgeon and Dr A. J. Beale for the rubella antisera, and the Peel Medical Research Trust for generous financial support.

\section{REFERENCES}

Best, J. M., Harcourt, G. C., O'Shea, S. and Banatvala, J. E. 1979. Rubella vaccines. Lancet, 2, 690.

Cappel, R. and De Cuyper, F. 1976. Efficacy and immune response to rubella subunits vaccines. Archs Virol., 50, 207.

FREESTONE, D. S. 1978. Efficacy of rubella vaccination. Br. med. J., 2, 697.

FREESTONE, D. S. 1979. Rubella: which vaccine? Lancet, 2, 858.

Horstmann, D. M., Liebhaber, H., Le Bouvier, G. L., Rosenberg, D. A. and Halstead, S. B. 1970. Rubella: reinfection of vaccinated and naturally immune persons exposed in an epidemic. New Engl. J. Med., 283, 771.

HoRWITZ, M. S. AND SCHARFF, M. D. 1969. Immunological precipitation of radioactively labeled viral proteins. In Fundamental techniques in virology, edited by K. Habel and N. P. Salzman, Academic Press: London, p. 297.

Ho-TERRY, L. AND COHEN, A. 1979. Radioimmunoassay for antibodies to rubella virus and its ribonucleoprotein component. J. med. Microbiol., 12, 441.

Le Bouvier, G. L. 1969a. Physicochemical characteristics of rubella antigens theta and iota. Nature, Lond., 221, 78.

Le BOUVIER, G. L. $1969 b$ Rubella precipitins. In Proceedings of 23rd International Symposium 
on Rubella Vaccines, edited by R. H. Regamey et al., symposia series in immunobiological standardisation 11, Karger: Basel, p. 133.

Le Bouvier, G. L. AND Plotkin, S. A. 1971. Precipitin responses to rubella vaccine RA27/3. J. inf. Dis., 123, 220.

LIEBHABER, H. 1970. Measurement of rubella antibody by hemagglutination inhibition. II. Characteristics of an improved HAI test employing a new method for the removal of non-immunoglobulin HA inhibitors from serum. J. Immun., 104, 826.

McCollum, R. W., Randolph, M. F., Byrne, E. B. ANd Hilleman, M. R. 1969. Rubella virus vaccine (HPV-77-DE5). Antigenic and protective efficacy in a community trial. Am.J. Dis. Child., 118, 186.

Pattison, J. R. AND DANE, D. S. 1975. The routine serological investigation of cases and contacts of rubella. J. Hyg., Camb., 75, 91.

Paul, N. R., Rhodes, A. J., CAMPBell, J. B. ANd Labzoffsky, N. A. 1974. Rubella precipitin response in natural infection and in vaccination. Arch. ges. Virusforsch., 45, 335. 